

\title{
From The History Of The Legal Basis Of The Policy Of Political Limitation Of The Ownership In Uzbekistan (1925- 1929)
}

Dilshad Rustambekovich Akhmedov

Independent Researcher At Andizhan State University, Republic Of Uzbekistan

Journal Website:

http://usajournalshub.c om/index,php/tajssei

Copyright: Original content from this work may be used under the terms of the creative commons attributes 4.0 licence.

\section{ABSTRACT}

The article analyzes the characteristic features of the policy of deprivation of electoral rights of the Soviet authorities held in Uzbekistan in 1925-1929. The essence of normative documents on the deprivation of suffrage was clarified, the social composition of the deprived of electoral rights was studied, statistics on the number of persons deprived of electoral rights in Uzbekistan in 1925-1929 were presented.

\section{KEYWORDS}

Election campaign, suffrage, constitution, election instruction, "kulak" enterprises, "deprived people", "unkulakned items".

\section{INTRODUCTION}

During the period of land and water reform in Uzbekistan in 1925-1929, the Soviet government pursued a policy of political and economic restrictions on the so-called "kulaks" of the self-sufficient, enterprising peasantry.
The political restrictions on "kulak" farms were mainly reflected in the deprivation of the right to vote. During these ykulaks, traders, owners of industrial and handicraft means of production, priests, officials of the former 
tsarist government and khan-amir, landowners, "kulak" farms were deprived of the right to vote.

The Communist Party also seized power in Uzbekistan, artificially accelerating the sociopolitical processes in the republic by means of administrative command, and ignored the real situation in the republic. As a result, the sociopolitical processes in Uzbekistan have become more controversial. The ruling Communist Party artificially divided members of society into "workers" and "non-workers" and intensified the conflict between them. On the one hand, the communist regime seeks to "stir up" the political activism of the "working masses" and involve them in party-state structures and public organizations, and on the other hand, it seeks to restricted his participation in political life on the basis of Soviet law. At the same time, he carried out constant work against them.

The measures of social deprivation of suffrage enshrined in the Constitution of the RSFSR, adopted in 1918 after the establishment of Bolshevik rule in the Soviet state, were initially considered by the party-state leadership as a temporary measure to protect the achievements of the revolution. Its main purpose was to prohibit the active participation of economically independent and influential people in political life in prerevolutionary society. Gradually, the deprivation of the right to vote became a powerful tool in changing the social environment in Soviet society. The government has made extensive and effective use of disenfranchisement measures as a means of discriminating against social strata.

\section{METHODS}

The Constitution of 1918 set out the general general rules concerning the structure of the state at the center and at the local level. The basic rules on elections were defined at the $\mathrm{VI}$ Congress of the All-Union Central Election Commission in December 1918 and approved by the Congress. "It is important to pay special attention to the fact that only those who have this right should participate in the elections," he said. Kulaks and counter-revolutionaries are deprived of the right to vote under the Soviet Constitution, the right to vote is given only to the poor and the working middle class ... the exploiting elements, the landlords, the kulaks are deprived of their rights as a result of the revolution they must have no influence on the election. Yesterday's exploiters were not allowed to run in the Soviet elections [2]. For several ykulaks, this guideline served as the only normative document that established a procedure for determining the category of persons deprived of the right to vote in local council elections to the central government.

\section{RESULTS AND DISCUSSIONS}

In 1921, in the Turkestan ASSR, the Soviet election campaign for local councils intensified. Special guides were sent to the places to lead the elections, the party and Soviet organizations mobilized all the propaganda and agitation forces at their disposal, and meetings and rallies were held everywhere. In order to conduct the election campaign "properly", by-elections were held in many places, during which "hostile elements" were "neutralized" by administrative means, "representatives of the upper class of feudalrich" were exiled, and the poor were intimidated [3]. 
In late August 1922, a new election directive was issued by the All-Union MIC. His section on disenfranchisement largely repeated the provisions of Article 65 of the 1918 Constitution of the RSFSR and the December 1918 election directive. According to the instructions, the list of those deprived of the right to vote will be compiled, checked and published by the relevant election commissions. In compiling the lists, the commissions were to use materials available to village and volost councils, and the list of "deprived" was to be published a week before the election.

On January 16, 1925, a new election directive was issued by the USSR Central Executive Committee. One of the main purposes of this instruction was to bring the process of disenfranchisement to the same level for all the allied republics. The new guideline was more democratic in content than the previous guidelines. As before, the provisions on deprivation of the right to vote were the same as in Articles 23 and 69 of the Constitution of the RSFSR and the relevant articles of the Constitutions of the Allied Republics. At the same time, it was clkulakly established that rural artisans and artisans with small auxiliary workshops would not be deprived of the right to vote. Representatives of the clergy were shown to be deprived of the right to vote only to clergymen whose occupation was a permanent occupation. The new guidelines stipulate that the list of those disenfranchised should be published 20 days before the election.

By the mid-1920s, the proportion of "deprived" was much lower in the country, accounting for $2 \%$ of all voters. The beginning of the new economic policy (NEP) and the associated liberalization processes in socio-political life were also reflected in the indicators of disenfranchisement. In other words, the number of those deprived of the right to vote decreased significantly, and in the election campaign of 1925-26, the number of “deprived" fell to its lowest level [7].

On December 16, 1925, by the decision of the Central Executive Committee of the Soviets of the Uzbek SSR No. 166 "On the Instruction on Elections to the Soviets", the election instruction [8] was approved. Section 2 of the Instruction is entitled "On persons deprived of the right to vote" and stipulates that persons belonging to or included in one of the following categories shall be deprived of the right to vote and be elected:

a) Persons who use hired labor for the purpose of kulak income.

b) Persons living on unkulakned income: those living on interest on capital; those who depend on the income from enterprises; those who make a living from income from buildings and structures; private traders and commercial intermediaries.

c) family members of officials of the Tsarist Russia, Bukhara Emirate, Khiva Khanate, as well as persons directly or indirectly involved in the management of the police, gendarmerie and other penitentiary institutions in the former tsarist, emirate and khanate governments and other counter-revolutionary governments; Kolchak, Denikin, Getman, Georgian Mensheviks, and other government officials: ministers, deputy ministers, department directors, governors-general, military and civil governors, senior officials, vice-governors, and ministers and officials of the former Bukhara Emirate and Khiva Khanate, for example: bird-high, bird-foot, kazikalon, udaychi, devonbegi, mirzaboshi, 
zakotchi, chairman and high-ranking officials under their authority; representatives of provinces and county nobility, officials on special assignments, senior chairmen, chairmen and members of the criminal department, as well as prosecutors and deputy prosecutors of judicial chambers, chairmen, members, prosecutors and assistant prosecutors of all types, members of regional and provincial administrations, zemstvo, heads of peasant and county administrations, officials of the police department at various levels, officials of the Ministry of Internal Affairs, officials of the General Directorate of Prisons of the Ministry of Justice, officials of the governments of the former Bukhara Emirate and Khiva Khanate corresponding to the above categories: agalyks, mirshabs, beks chairmen, bekchi, zindonboshi, amlokdors, officials, yasovulboshi, muftis, yasovuls with special assignments, guards, jevachi [9].

d) Monks and priests of all religions and faiths.

e) Persons under guardianship who have been duly diagnosed as mentally ill or mentally retarded.

f) Persons whose rights have been restricted or imprisoned by a court of law, or who have been temporarily deported by trial or administrative proceedings [10]. With the formation of the foundations of a totalitarian state, the range of persons deprived of the right to vote has expanded. Along with the representatives of the new Nepman bourgeoisie, artisans, small traders, and self-sufficient peasants were included in the list of "deprived" representatives of groups that had significantly improved their economic situation and achieved high social status under the New Economic Policy (NEP) were also disenfranchised. The foundations of the state policy in the field of deprivation of the right to vote were enshrined in the September 28, 1926 election directive of the Central Executive Committee of the USSR. Its preamble stated that "the Soviet elections of 1926 set the task of preventing the further infiltration of exploitative elements into the Soviets".

The resolution of the Presidium of the USSR Central Election Commission, which approved this instruction, emphasized that the executive committees of the allied republics "should not bring the exploiting elements of the population closer to the elections to ensure the protection of the rights of the working people".

For the first time in the history of the institute of deprivation of the right to vote, this Unionwide instruction of 1926 clkulakly and in detail set out the criteria on which the disenfranchisement of certain citizens was based. The main social groups deprived of the right to vote were: persons using hired labor, persons living on unkulakned income, "persons deprived of the right to vote during elections or previous activities on the basis of class status" marked. It was also stated that rural citizens who use hired labor for profit, as well as those who own industrial and handicraft enterprises and use hired labor, will be deprived of the right to vote. At the same time, farmers involved in trade, ie those engaged in the purchase and sale of livestock and agricultural products, were also included in the list of "deprived" [13].

This document identified the main features that belong to the category of "deprived" 
citizens. However, there was also uncertainty and confusion in the wording of this guideline, which defined the categories of those eligible to vote and those disenfranchised. This has led local authorities to act independently and arbitrarily in most cases on who to include in the electorate or who to disenfranchise. Most importantly, the main factor was not the fulfillment of the requirements of the Constitution and the instructions on elections, but the desire to demonstrate high performance in the fight against "laborless elements".

In 1926, the population of the Uzbek SSR was 4 million 637 thousand 885 people, of which 1 million 35 thousand 378 were urban and 3 million 602 thousand 507 were rural. The total population was 762,681 families or households. The 1926 election campaign was attended by 45.9 per cent of eligible voters throughout the country. The average farmer made up 30.8 percent of the electorate. In the social structure of the electorate, the share of farmers in individual regions was $35.2 \%$ in Fergana region, $34.9 \%$ in Samarkand, $26.6 \%$ in Tashkent region and $26.6 \%$ in Kashkadarya region [15].

Deprivation of the right to vote to farmers is mainly based on the amount of tax they pay, as well as their use of hired labor in agricultural work. It is known that under the New Economic Policy (NEP) in Turkestan, and later in Uzbekistan, private entrepreneurship was allowed, and in agriculture, farmers were partially allowed to use hired labor. As a result, commodity-money relations developed, the volume of production increased significantly, which in turn increased the incomes of individual groups of entrepreneurs and farmers. Such an increase in income put them at risk of being considered "kulak". According to Article 36 (c) of the Instruction on Elections to the Soviets of the USSR, farms using hired labor in the amount of 100 working days were deprived of the right to vote [16].

During the election campaign of 1926-1927, 145,790 people were deprived of the right to vote in the Uzbek SSR. Of those disenfranchised, 67,934 lived in cities and 33,029 in rural areas. $10.4 \%$ of those deprived of the right to vote in rural areas are "kulaks", $11.9 \%$ - those who kulakn without work (usurers, those who kulak income from renting housing, land and means of production), $13.9 \%$ - traders, $23.8 \%$ - priests , 8.4 per cent were former police officers, amir and khan officials, 1.6 per cent were mentally ill, 3.1 per cent were convicted and 27.9 per cent were from other categories [17]. The majority of those deprived of other categories were those who had been employed. This is because cotton farmers would have to hire additional labor during the peak season (manual sowing, cotton picking and cotton picking). Under such conditions, not only wealthy farms, but also middle-class and poor farmers would be forced to use hired labor.

During the election campaign, the Central Election Commission received 158 applications from those deprived of the right to vote. The applications were mainly made by middle - and poor farmers with 5-10 tanobs of land, who stated that they were disqualified only because of the use of part-time labor in agricultural work due to necessity. Of the 158 people who applied by the Central Election Commission, only 17 had their voting rights restored, 87 were rejected, and 54 were sent to places for reconsideration.

During the election campaign, in addition to depriving people of the right to vote for 
various reasons and grounds, "cleansing" of the lower election commissions was carried out. In particular, "kulak-rich" and "anti-Soviet elements" who were included in the commissions were excluded from the commission. The Khojand District Election Commission expelled 8 people and 2 chairmen from the rural election commissions in the district for alcoholism and contact with the rich. The Andizhan district election commission completely dissolved 3 district election commissions and expelled 20 people from other district commissions and 65 people from rural election commissions. Half of them were disenfranchised. The Surkhandarya district election commission expelled 3 rich people from the district election commissions, the Ferghana district election commission expelled 4 people from the district commissions as "anti-Soviet elements" and 79 people from the village commissions, 19 of whom were chairmen of rural election commissions [19].

In March 1927, the Second Congress of Soviets of Uzbekistan adopted the Constitution of the Republic, which was strictly class-based and was imbued with the ideology of Bolshevik extremism. According to the Constitution, many social groups, believers and others from "non-working" groups were deprived of the right to vote. Thus, a large part of the population was excluded from participation in state building and socio-political life by the communist regime.

Deprivation of the right to vote in the country has continued in recent ykulaks, and the number of "deprived" has increased. In 1928, 96,157 voters were registered in Surkhandarya district, and 5,949 people ( $6.2 \%$ of the total number of voters) were disenfranchised in the district. The social composition of the deprived was as follows: 841 “kulaks”, 1296 people living on unkulakned income, 615 merchants and grocers, 1486 priests, 807 former emir officials, 45 mentally ill people, 186 convicts, other categories (those who took part in "printing", used hired labor, etc.) - 673 [20]. In the old city of Bukhara, 3,330 people (2,305 men, 1,025 women) were deprived of the right to vote, convicted -8 , priests - 508, mentally ill - 5, deprived of other reasons - 32 [21].

According to the Andizhan district election commission on September 1, 1929, 21,928 people had been disenfranchised in the district so far. Of these, 4,133 were small entrepreneurs, 3,415 were "kulaks", 2,543 were merchants, and 5,620 were priests.

At the meeting of the commission of the 2nd session of the Central Executive Committee of the Uzbek SSR on October 6, 1929, the applications of those deprived of the right to vote in the Fergana district were considered. The session was held in Ferghana and was chaired by Jahon Obidova. At this meeting, a total of 72 applications for the restoration of suffrage were considered, of which 29 were reinstated, the remaining 43 were rejected, including 8 applications were sent to the relevant district commissions for reconsideration. For example, the application of Haydar Rizakulov, who lived in the village of Yangichek, Kokand region, was a petty trader and usurer until 1926, and stopped his activities in 1926, was rejected [23].

In 1929, a total of 119,305 people were deprived of the right to vote in the Uzbek SSR. Of these, 13,555 were "kulaks", 15,976 were kulakners, 17,422 were merchants, 28,459 were priests, 8,984 were former police officers, former emirs and khan officials, 4,010 were convicted, 2,086 were mentally ill, and 26,173 were of other categories [24]. 
In 1929, the Central Commission for the Review of Complaints and Appeals of Disenfranchised Persons held 18 meetings, in which a total of 796 complaints were considered. The suffrage of 277 people was restored, 209 cases were sent for additional investigation and 310 applications were rejected.

\section{CONCLUSION}

In general, it can be concluded that the election campaigns of 1925-1929 were aimed at politically restricting the affluent, wealthy classes of the rural population, in the process of which many injustices and the practice of extreme measures were widely used. The policy of the Bolshevik regime aimed at the abolition of private property, the growth of social and state property in all spheres of economic life, the extreme centralization of economic management, as well as the use of administrative rather than economic methods aggravated the current socio-political situation in Uzbekistan.

\section{REFERENCES}

1. New history of Uzbekistan. The second book. Uzbekistan in the period of Soviet colonialism / Compilers: M.Juraev, R.Nurullin, S.Kamalov and others. - $\mathrm{T}$ : Shark, 2000. - p. 312-313.

2. Collection of Legalizations and Orders of the Workers and Peasants Government of the RSFSR.1917-1918. No. 86 - p. 901.

3. The policy of plundering the national wealth of Uzbekistan by the dictatorial regime: the testimony of history and lessons (1865-1990). / Project Manager and Editor-in-Chief: D.A. Alimova. Tashkent: Shark, 2000. - p. 93.
4. Collection of Legalizations and Orders of the Workers and Peasants Government of the RSFSR. 1922. No. 56 - p. 706.

5. Collection of Laws and Orders of the Workers and Peasants Government of the USSR.1925. No.6. - p. 55.

6. Valuev D. Licenses in the system of social relations (1918-1936) - Moscow: 2012 .-p. 45.

7. Salamatova M.S. Deprived of suffrage in Soviet Russia. 1918-1936: Results of the study. // Marginals in Soviet society of the 1920-1930s. - Novosibirsk: Publishing House Novosibirsk State University, 2001 .p.28.

8. National Archives of the Republic of Uzbekistan, R-86-Fund, List-1, Folding Volume-2218, p.129-132.

9. National Archives of the Republic of Uzbekistan, R-86-Fund, List-1, Folding Volume-2218, p.129-130.

10. National Archives of the Republic of Uzbekistan, R-86-Fund, List-1, Folding Volume-2218, p.130.

11. Kukushkin Yu.S. Village Councils and the class struggle in the countryside (19211932). - Moscow: 1968.-p. 55.

12. Collection of Laws of the USSR, 1927, No.12. - P. 129.

13. Trifonov I.Ya. The elimination of the exploiting classes in the USSR. - Moscow: 1975 -p. 123-124.

14. National Archives of the Republic of Uzbekistan, R-837-Fund, List-1, Folding Volume-161, pp.15-16.

15. National Archives of the Republic of Uzbekistan, R-837-Fund, List-1, Folding Volume-161, p.46.

16. National Archives of the Republic of Uzbekistan, R-86-Fund, List-1, Folding Volume-5044, p.15. 
17. National Archives of the Republic of Uzbekistan, R-86-Fund, List-1, Folding Volume-5023, pp.39-42.

18. National Archives of the Republic of Uzbekistan, R-86-Fund, List-1, Folding Volume-5023, p.42.

19. National Archives of the Republic of Uzbekistan, R-86-Fund, List-1, Folding Volume-5023, p.43.

20. National Archives of the Republic of Uzbekistan, R-86-Fund, List-1, Folding Volume-5044, p.83.

21. National Archives of the Republic of Uzbekistan , R-86-Fund, List-1, Folding Volume-5044, p.131.

22. Andizhan Province State Archive, Fund189, List-1, Folding Volume - 392, -P.41.

23. Ferghana Province State Archive, Fund324, List-1, Folding Volume - 361, -P.162.

24. National Archives of the Republic of Uzbekistan, R-86-Fund, List-1, Folding Volume-5044, p.197. 